Journal of the Society for the Study of Architecture in Canada Le Journal de la Société pour l'étude de l'architecture au Canada

\title{
If These Walls Could Talk
}

Domestic Architecture as Documentation of Women's Histories in the Wyatt Historic House Museum

\section{Leanne Gaudet}

Volume 44, numéro 1, 2019

Women and Architecture

URI : https://id.erudit.org/iderudit/1066281ar

DOI : https://doi.org/10.7202/1066281ar

Aller au sommaire du numéro

Éditeur(s)

SSAC-SEAC

ISSN

2563-8696 (numérique)

Découvrir la revue

Citer cet article

Gaudet, L. (2019). If These Walls Could Talk: Domestic Architecture as Documentation of Women's Histories in the Wyatt Historic House Museum. Journal of the Society for the Study of Architecture in Canada / Le Journal de la Société pour l'étude de l'architecture au Canada, 44(1), 31-44.

https://doi.org/10.7202/1066281ar d'utilisation que vous pouvez consulter en ligne. 


\section{IF THESE WALLS COULD TALK Domestic Architecture as Documentation of Women's Histories in the Wyatt Historic House Museum}

LEANNE GAUDET holds an M.A. in Art History from Carleton University. Originally from Prince Edward Island, she currently lives in Ottawa where she works as a research associate for Know History, a historic services firm that strives to research, document, and present Canada's history.

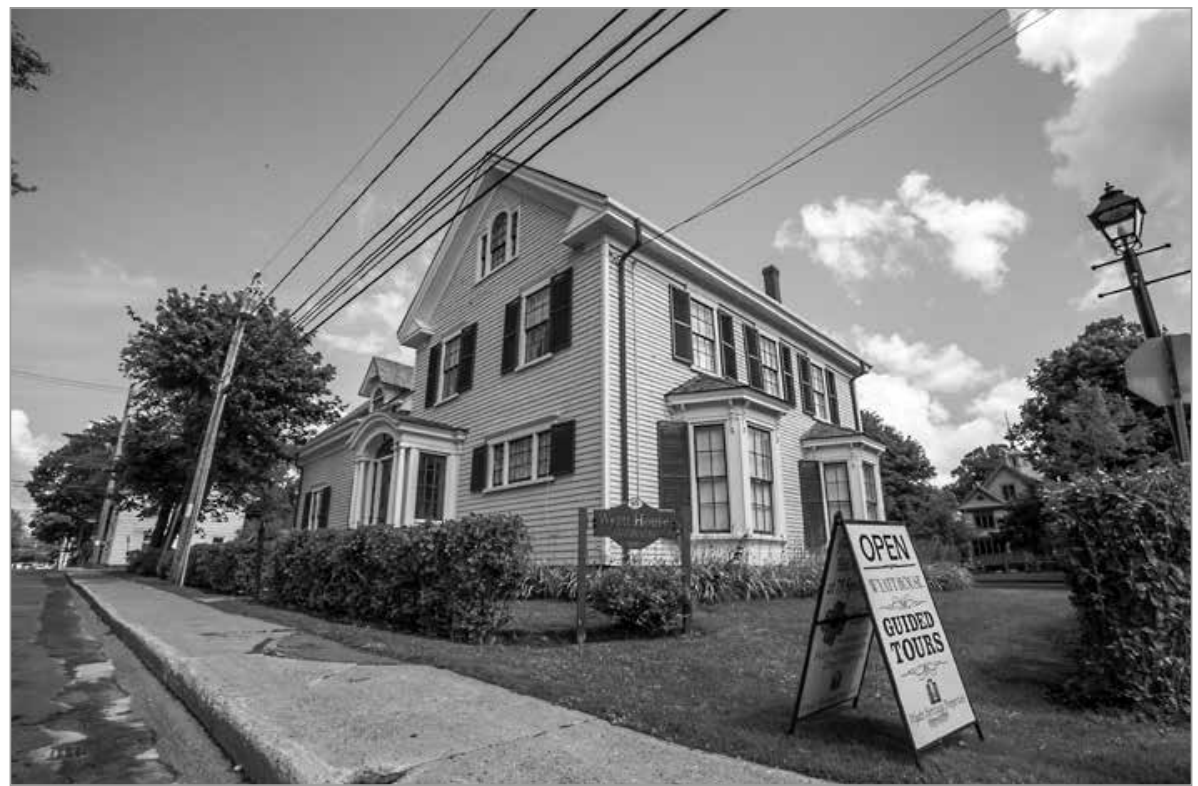

FIG. 1. THE WYATT HISTORIC HOUSE MUSEUM OR "WYATT HOUSE," LOCATED AT 85 SPRING STREET IN SUMMERSIDE, PRINCE EDWARD ISLAND. | ADAM KIRKEY, 2014.

$>$ LEANNE GAUDET

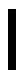
n June 1913, Ned Wyatt, a prominent lawyer and politician in Prince Edward Island, wrote the following to his wife, Cecelia, who had long suffered from chronic gastrointestinal and respiratory troubles:

\footnotetext{
My darling little girl, your treatment is just like housecleaning. You are eliminating a lot of morbid matter that is only harmful and like some offensive material around the house it is better out than in and when gotten rid of the whole environment has a healthier and pleasant condition. ${ }^{1}$
}

In comparing Cecelia's ailing body to a house, Ned manifested the period's insistent association between women's bodies and domestic interiors. This excerpt-taken from one of hundreds of letters written between the four members of the Wyatt family-introduces the compelling and layered histories of women, their bodies, and domestic spaces that are present in the Wyatt Historic House Museum, located in Summerside, Prince Edward Island.

This essay argues that historic house museums can be reconceptualized to serve as effective sites of narration for important and seldom acknowledged women's histories. Despite the nineteenth and early-twentieth centuries correlation between women and domestic spaces, many Canadian house museums were created to preserve the histories of prominent male figures from our past. I argue that the Wyatt Historic House Museum operates outside of that model and is a unique example of a house museum that highlights diverse women's 
histories and narratives through its architectural structure and collection of objects and furnishings. The curated mix of original decor and furnishings in the rooms of the house largely reflects what the home would have looked like during the early 1900s through the 1920s, with the exception of the kitchen and the upstairs washroom, which date to the 1950s. These diverse time periods represent the years that the Wyatt family members resided in the house together and were the most active as a family unit. These years also coincide with a time when the home and "domestic sphere" were strongly associated with the periods' constructed ideals of middle- and upperclass women. The Wyatt House was the home of the same family for a century, which provides us with a unique understanding of how a home physically changes over time to serve the various needs of its residents. As I explore here, the intimately connected themes of health, women's bodies, and domestic spaces played a prominent role in the lives of the four Wyatt family members, as clearly demonstrated through family letters, personal objects, and the architecture of their home. Like many historic house museums in Atlantic Canada, the Wyatt House is a site that has yet to be examined from a critical perspective. I argue that it serves as a valuable case study in understanding how the architecture of a home can be considered as a historic document that reveals personal histories of past inhabitants.

\section{THE GREAT MAN HOUSE} MUSEUM GENRE

Recent scholarship has examined house museums in diverse contexts, including contemporary museum practices, tourism, discussions of local history and heritage, notions of constructed narratives and authenticity, and "founding nations" mythology. ${ }^{2}$ The house museum's origins are deeply rooted in the traditions of the cabinet of curiosity, bourgeois collections, historical societies, and the "popular phenomenon of period rooms." ${ }^{3}$ Historian Patricia West acknowledges that the establishment of house museums in North America was motivated by cultural politics and nationalistic identity. ${ }^{4}$ Underlying these motivations is the belief that house museums are largely recreated-and sometimes even invented-spaces that serve the purpose of functioning as static time capsules. Upon entering a house museum, visitors can engage with an earlier time period and way of life by viewing and occasionally interacting with the domestic space and objects on display. ${ }^{5}$ The experience of visiting these sites is often enhanced by the tendency of house museums to be directly linked to an important historical figure whose memory and influence are presented as permeating the space itself. ${ }^{6}$ The preservation of homes that belonged to historically significant figures is what scholar Charlotte H.F. Smith has deemed "the Great Man house museum genre." 7 This genre presents wholesome, patriotic histories that highlight the achievements and biographies of prominent male figures in an attempt to foster feelings of nationalism. While the end of the twentieth century saw the incorporation of social history into museums and house museums alike, to this date not much has changed in terms of the inclusion of alternative histories in contemporary house museums in Canada. ${ }^{8}$

While there are some exceptions, and while representations of women are occasionally included in these popular male-centric sites, the "feminine" elements included in the average house museum tend to focus on important, yet often generalized female domestic responsibilities such as cleaning, cooking, and childcare. ${ }^{9}$ Historically, women often campaigned for the establishment of historic sites-house museums included. The active involvement of women in establishing historic house museums problematizes the fact that today many of these institutions fail to acknowledge women's narratives..$^{10}$ Although an initial motivation to preserve the homes of prominent male figures was to allow for a more intimate examination of these public figures' private lives, the focus on men within house museums is ironic. The home, so often associated with socially constructed ideals of women, female bodies, and the private, domestic sphere, has been preserved and represented as a largely male-centred site because of the prominent public roles of selected men and the connection they have to a national identity. ${ }^{11}$ Additionally, while recent scholarship has described the complications associated with separate sphere ideology, proving that men and women often operated within both spheres albeit in different capacities, many house museums have not followed suit. ${ }^{12}$ Not only do many house museums neglect valuable histories associated with women and domestic interiors, but they also fail to acknowledge the agency women had in their own homes, the roles women played in the public sphere, and the influence men had in the domestic sphere. I argue that as previously inhabited, private spaces, historic house museums can be regarded as sites that complicate separate sphere ideology through their public exploration of past lives. The lived experiences of many women during these periods were truly rooted in the home; thus, much can be learned through the study of domestic spaces as a means of gaining insight into specific women's histories. 
THE FEMINIZATION OF SPACE: WOMEN AND DOMESTIC INTERIORS

Frequently operating as a series of historic period rooms complete with a collection of domestic objects, house museums are unique in their categorization as being both a past domestic space and a museum. While house museums ostensibly function as static, uninhabited interiors, they were once private dwellings, and the presence of objects suggests traces of the lives led in these spaces. Indeed, house museums rely on the power of objects to provide a tangible and visible connection to a past, experienced time and offer rich opportunities for material culture analysis. ${ }^{13}$ The house itself can be conceptualized as an object of material culture, standing as evidence of lives lived in the past. Following the object-based theory described by art historian Jules David Prown, houses are reflections of social, cultural, and individual beliefs and experiences. ${ }^{14}$ Their spaces are extensions of and witnesses to the intimate lives of individuals, and much can be gleaned from studying their material composition; as Jean Baudrillard states, "to study the nature of the interior of a building is to study the culture of the people who occupy those inside spaces."15

Annmarie Adams and Silvia Spampinato exemplify how the analysis of a house museum's architecture can reveal and complicate women's histories with their case study of Carrollcroft House, located in Stanstead, Quebec. ${ }^{16}$ Through the examination of letters, diary entries, paintings, photographs, wills, and insurance plans, these authors ask specific questions about the architecture of the Victorian-era home: "What does the house itself tell us about the Colby family? What is the role of domestic architecture in the construction of family and gender identity?" and lastly, "How did family members shape the house according to their needs?"17 As they answer these questions they discuss how the three female figures of the home regulated and "feminized" their living environment by shifting the ways different spaces in the home were used, depending on the needs of the family. Here, "feminized" refers to the cultural and social agency women held in physically altering or using a domestic space for personal necessity or desire. In discussing the life of Hattie Colby [1838-1932], Carrollcroft's female head-of-house, Adams and Spampinato note that while she often adhered to the traditional way rooms would be used in a Victorian home, Hattie also operated outside of these rigid frameworks. Hattie's use of the back portion of the home's front parlour as her bedroom in the later years of her life, for example, demonstrates a feminized use of space that "favored practicality and her comfort over the formality of the typical Victorian living room." ${ }^{18}$

Adams and Spampinato's feminist framework enlightens my study of the Wyatt house. Like them, I adopt a material culture methodology to "read" a domestic dwelling as a telling document about the members of the Wyatt family. Conceptualizing homes as material evidence of past lives can revise histories of under-represented individuals, communities, and cultures. The period during which the Wyatts occupied their residence in Summerside was a time when the home and its contents were largely viewed as expressions of status and extensions of the self. ${ }^{19}$ The Wyatt Historic House Museum, functioning as both an object and rich archive of letters, diaries, objects, and furnishings, presents an excellent opportunity to both explore the intimate connections between domestic spaces and women's histories and answer questions about the agency women exercised in their own homes.

\section{CONTEXTUALIZING THE WYATT HOUSE: PRINCE EDWARD ISLAND IN THE NINETEENTH AND TWENTIETH CENTURIES}

As a province that is often associated with rural agricultural landscapes and idyllic seaside communities, Prince Edward Island's urban culture was significantly affected by shipbuilding, mercantile, and fox-farming industries. Although they housed less than fifteen percent of the Island's population, "the Island's two major settlements, Charlottetown and Summerside," as historian Edward McDonald explains, "provided a counterpoint to the pastoral landscape. They were more socially stratified, more ethnically mixed, and more economically diverse than rural Prince Edward Island."20 The Island's social histories are rooted in land ownership disputes, politics, agriculture, and industry and are often told from a male-centric perspective. While rural agricultural- and fishing-based communities were the daily reality for many men and women alike, the Island's urban histories must not be excluded from the province's broader narrative. Although little scholarship exists that critically discusses the experiences of historic upper- and middle-class Island women, their histories have often been broadly contextualized by what has been written about other Victorian and Edwardian women living in urban environments. ${ }^{21}$

The Wyatt residence helps to understand a wider context that surrounds Prince Edward Island's well-known industrial and political histories, particularly as it pertains to the Island's upper-class women. As members of the Island's social elite, the Wyatt family benefitted from the province's burgeoning industries. In particular, the role of Cecelia's father in the shipbuilding industry ensured a high social standing for the members of his family. ${ }^{22}$ Commenting 


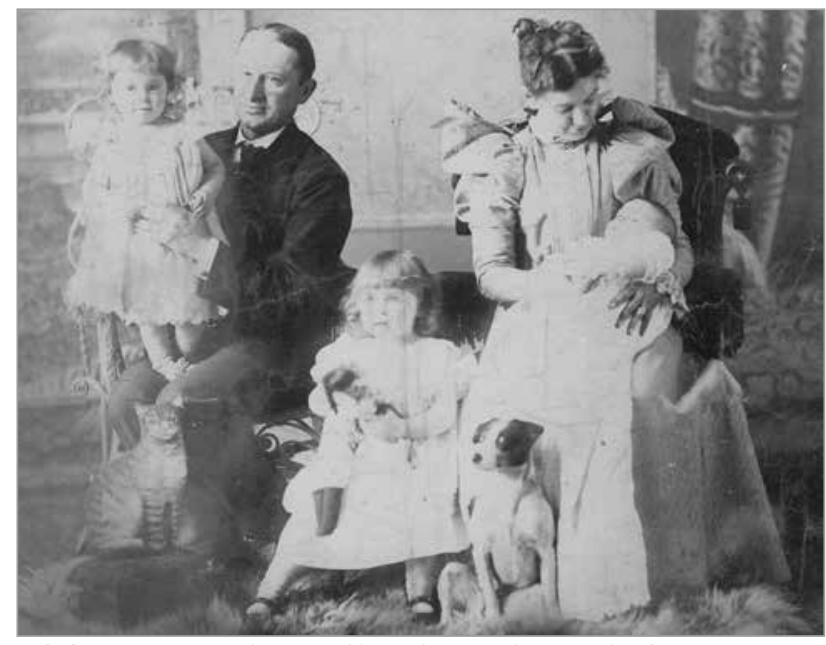

FIG. 2. WYATT FAMILY PORTRAIT, 1897. IN ORDER FROM LEFT TO RIGHT: WANDA, NED, DOROTHY, CECELIA HOLDING BABY IVAN. | COURTESY OF MACNAUGHT HISTORY CENTRE AND ARCHIVES.

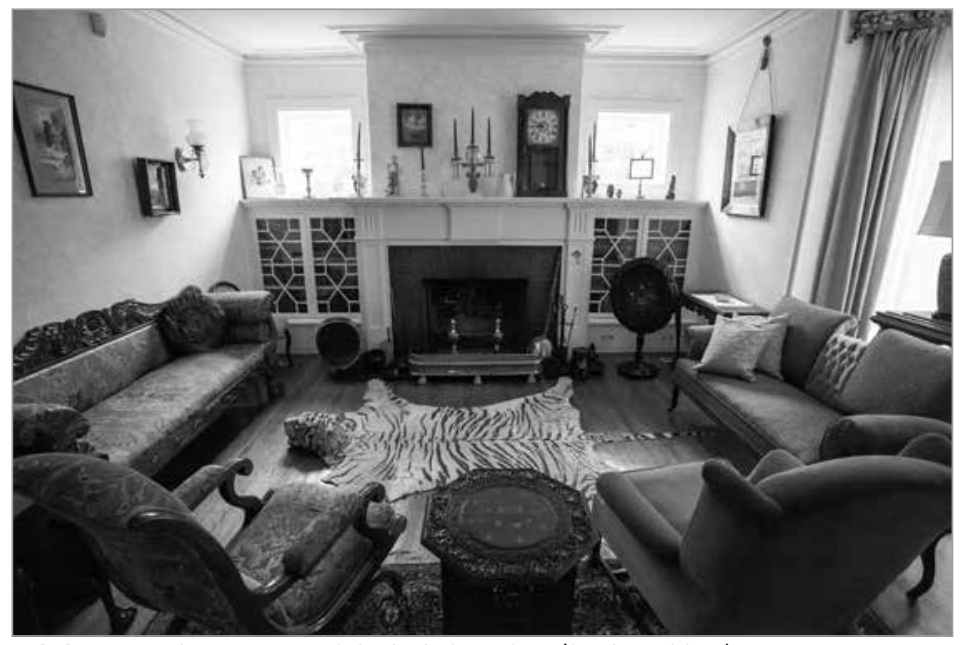

FIG. 3. FAR END OF THE WYATT HISTORIC HOUSE MUSEUM'S FRONT ROOM. | ADAM KIRKEY, 2014. on the presentation of women in Prince Edward Island local newspapers at the beginning of the twentieth century, Mary McDonald-Rissanen notes that an examination of these publications suggests that there was no "pivotal place for women in society other than being beautiful, healthy, and fit for reproduction," emphasizing the societal limits that were often placed on women during that time. ${ }^{23}$ The prescribed lifestyle of separate sphere ideology is most applicable in understanding the life of Cecelia Wyatt because she was raised during the Victorian era. Her daughters, primarily raised during the Edwardian years, were likely brought up following the beliefs and practices that were inherent in that ideology. However, an investigation of the architectural spaces that were occupied by Wanda and Dorothy provides a deeper understanding of each woman's own lived experiences. Objects on display in Dorothy's bedroom frame a narrative of decorative arts pursuits that aligns in many ways with the assumptions made about high-society Edwardian women, while Wanda's bedroom suggests a narrative of education and travel that subverts this ideological framework. I argue that the presence of both narratives in the home, in addition to the framing of their mother Cecelia's lived experience, emphasizes the fact that the lives of early twentieth-century women were varied, complex, and individualized, despite the generalized histories of women that are included in many historic house museums.

\section{THE WYATT HOUSE}

The Wyatt Historic House Museum is located on the corner of Prince and Spring streets in downtown Summerside (fig. 1). Constructed in 1867, the modest-sized, pale yellow Georgian-style home with dark green shutters is situated within the city's current historic district-an area praised for its numerous nineteenth-century houses that boast a variety of architectural styles. Visitors to the museum are introduced to the home's early history and the members of the Wyatt family: originally owned by local merchant Robert Strong, the Wyatt House went up for auction in 1887 and was purchased by the Honourable John E. Lefurgey [1824-1891], a local shipbuilder and merchant who lived in a large Gothic Revival home right across the lawn from the house. ${ }^{24}$ As Lefurgey already had a large home of his own, family lore states that John Lefurgey gifted his new purchase to one of his daughters, Cecelia [1864-1937], on the occasion of her marriage in 1890 to James Edward Wyatt [1860-1932], a prominent lawyer and politician from Charlottetown. ${ }^{25}$ Following their marriage, Ned and Cecelia moved into their new home and welcomed the birth of their first daughter, Dorothy, in 1893. Their second daughter, Wanda, was born two years later in 1895, and their son Ivan, in 1896. The latter, sadly, died at the age of two from a childhood disease. The Wyatt House, as it came to be known, was witness to the life of this four-person family (fig. 2).

Throughout her life, Wanda was one of the Island's strongest supporters of arts, heritage, and culture. In 1966, she created the Wyatt Foundation to manage her numerous philanthropic projects, and she also acquired her grandfather Lefurgey's home with the intent to preserve its architectural integrity and transform the home into a community cultural centre. Before her passing in 1998 at the age of 102, 


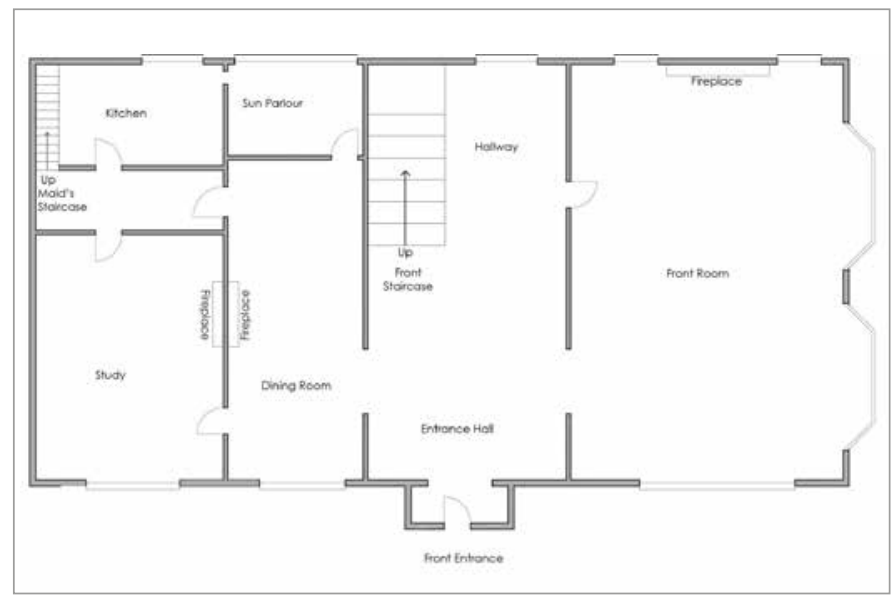

FIG. 4. FLOOR PLAN OF THE FIRST FLOOR OF THE WYATT HISTORIC HOUSE MUSEUM (NOTE: PLAN IS NOT TO SCALE). | JESSICA KIRKHAM.

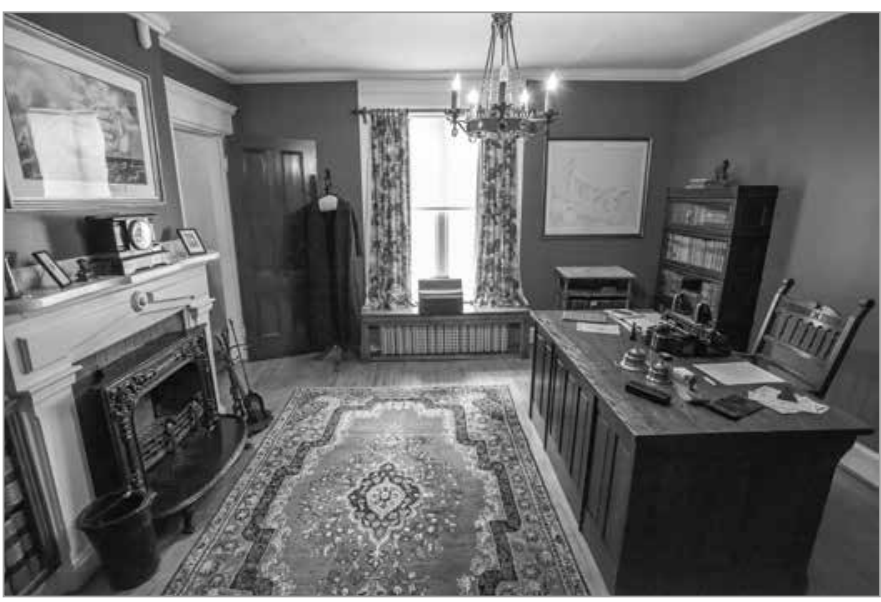

FIG. 5. NED WYATT'S STUDY OR OFFICE IN THE WYATT HISTORIC HOUSE MUSEUM. | ADAM KIRKEY, 2014.
Wanda Wyatt expressed her hope that the Wyatt family home, complete with its original furnishings, letters, photographs, and personal documents, would also be preserved as a house museum for the community. In 1999, the two properties were transferred from the Wyatt Foundation to the City of Summerside, and the Wyatt House was opened as a house museum in 2001 after going through an extensive restorative, curatorial, and cataloguing process. The Wyatt Historic House Museum, the Lefurgey Cultural Centre, a neighbouring building called the MacNaught History Centre and Archives, as well as a few other historic properties continue to be managed by Culture Summerside, a division of the City of Summerside. ${ }^{26}$

Regardless of its rather unassuming exterior, visitors are greeted with physical signifiers of the Wyatt family's social standing upon entering the Wyatt Historic House Museum for interpretive guided tours. With its ornate furnishings and objects of curiosities, the living room, for example, emphasizes the Wyatts's status as educated, privileged members of the Island's upper class who often hosted meetings and other social events in that space (fig. 3). ${ }^{27}$ The tours provide open access to every room in the house, with the exception of the attic and basement, allowing guests to fully enter each room of the home and closely examine the array of objects on display. The museum prides itself on the fact that most of the items in the home are original to the house and the Wyatt family, although it is acknowledged that each of the rooms has been set up to replicate what the home looked like for the first half of the twentieth century based on photographs, journal entries, and letters written by the Wyatt family. Throughout the tour, items of aesthetic, historic, and narrative interest are highlighted. Although selectively curated, I argue that the intimate and personalized spaces of the Wyatt House successfully contextualize the individual personalities and interests of the Wyatt family members.

\section{INTERIORS AS SELF-PORTRAITS: SPACES IN THE WYATT HOUSE}

In addition to the living room, the main level of the home includes the Wyatt family's dining room, which leads to Ned's home office or study (fig. 4). Painted a deep shade of red, the study houses various objects that symbolize ideals of the Edwardian male-head-of-house and is the only space in the Wyatt House dedicated to telling the history of Ned's public life outside the home (fig. 5). The work Ned did in that space is made obvious through the display of his large wooden desk, which features Ned's Oliver typewriter, cheque books, and inkwell. However, the narrative of the space is complicated by the presence of a low armless rocking chair and an ornate wooden sewing table. Tour guides often explain how Wyatt family diaries and letters indicate that Cecelia also spent time working in that room (fig. 6). ${ }^{28}$ Although tours typically point out Cecelia's presence in the study as an interesting fact about the Wyatt family dynamics, I argue that the chair also subtly disrupts the masculine atmosphere of the space. The presence of items used by Cecelia complicates common assumptions about the gendered use of space and separate sphere ideology. Ned's study serves as a valuable example of how a historic house museum's interior can be 


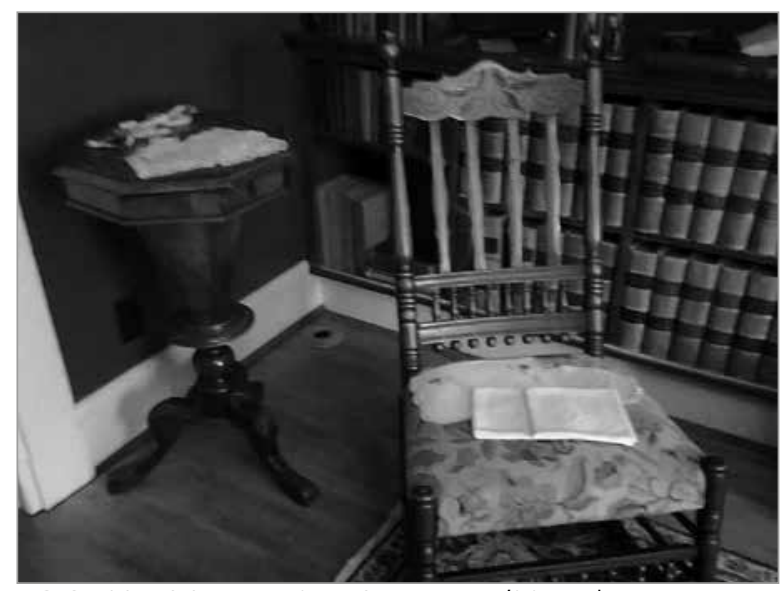

FIG. 6. ROCKING CHAIR AND SEWING TABLE IN NED'S STUDY. | ADAM KIRKEY, 2014.

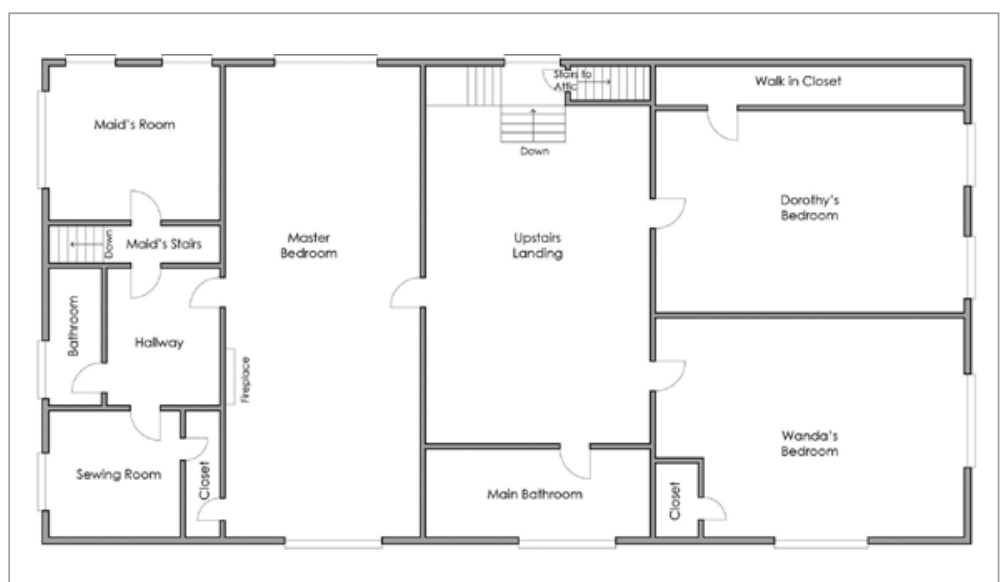

FIG. 7. FLOOR PLAN OF THE SECOND FLOOR OF THE WYATT HISTORIC HOUSE MUSEUM (NOTE: PLAN IS NOT TO SCALE). | JESSICA KIRKHAM.

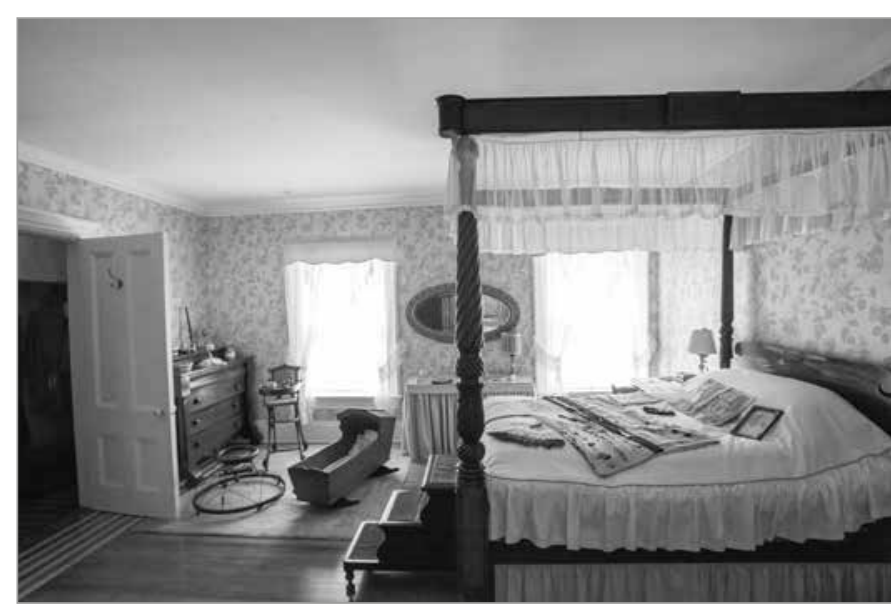

FIG. 8. DOROTHY WYATT'S BEDROOM FEATURING WALK-IN CLOSET, FOUR-POSTER BED, AND NURSERY FURNITURE. | ADAM KIRKEY, 2014.

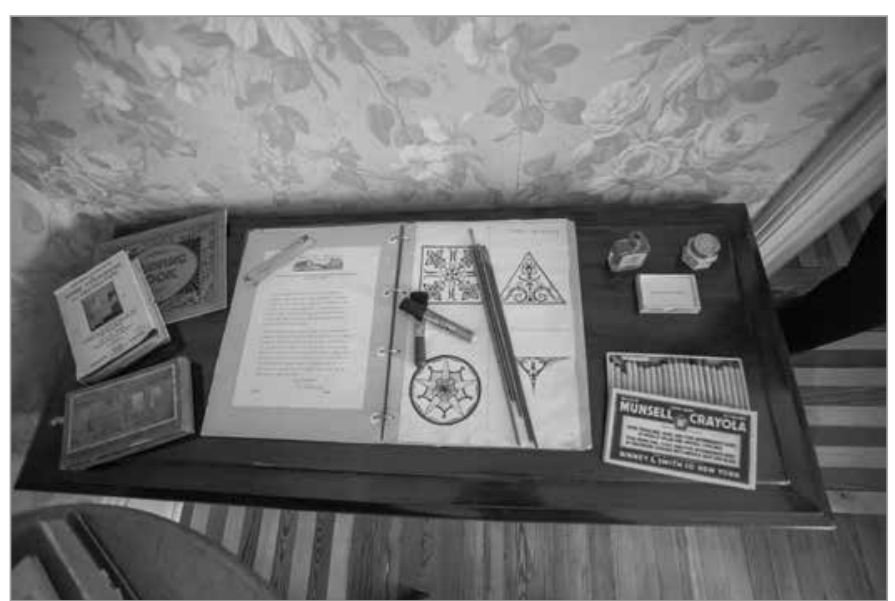

FIG. 9. A SELECTION OF DOROTHY WYATT'S ART SUPPLIES ON DISPLAY IN HER BEDROOM. | ADAM KIRKEY, 2014. used to contest previously held assumptions about separate sphere ideologies.

Further women's histories are conveyed in the interior design of Dorothy and Wanda's bedrooms, located on the second floor of the home (fig. 7). On the upstairs landing of the Wyatt House, the first door on the left provides entry into Dorothy's bedroom (fig. 8). Decorated with a soft cream and silver wallpaper, the space houses Dorothy's ornately carved wooden four-poster bed and features her luxurious walk-in closet. The baby furniture that was used by all three
Wyatt children-including a highchair, a cradle, and a walker-is also displayed in Dorothy's room, despite its lack of association with the nursery; a curatorial decision made to reference Dorothy's inclination toward a traditional "domestic life." Dorothy's other domestic interests are referenced in her bedroom; a love of interior design is reflected in her handmade bed skirt and matching vanity desk cover, ${ }^{29}$ and an array of her art supplies displayed on a wooden hope chest gives evidence of her artistic pursuits (fig. 9). Taking her interest in design seriously, Dorothy enrolled at Mount
Allison University in 1929 to take classes in "Art Structures, History of Art Design, Prospections, and Interior Modelling." 30 In addition to this interest in fine arts, she also had a love of music and singing. Even before she attended Mount Allison, she travelled to Toronto to take singing lessons with several different instructors. The initial entry in one of Dorothy's four diaries begins with a reflection on leaving the island to pursue an education in music:

Well here I am in Toronto and so far the experience has been fine. I left home Fri. 


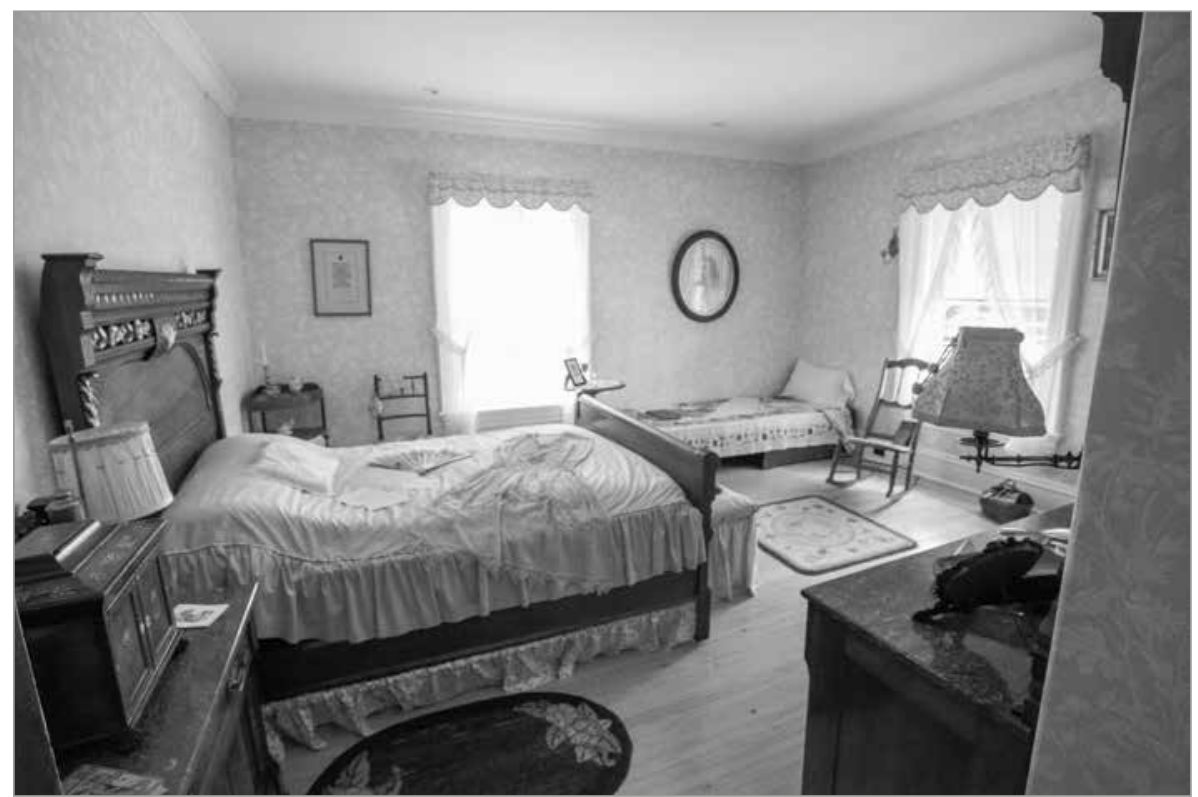

FIG. 10. WANDA WYATT'S BEDROOM UNTIL 1937. AFTER 1937-THE YEAR CECELIA WYATT PASSED AWAY—WANDA MOVED INTO THE MASTER BEDROOM OF THE HOME. | ADAM KIRKEY, 2014.

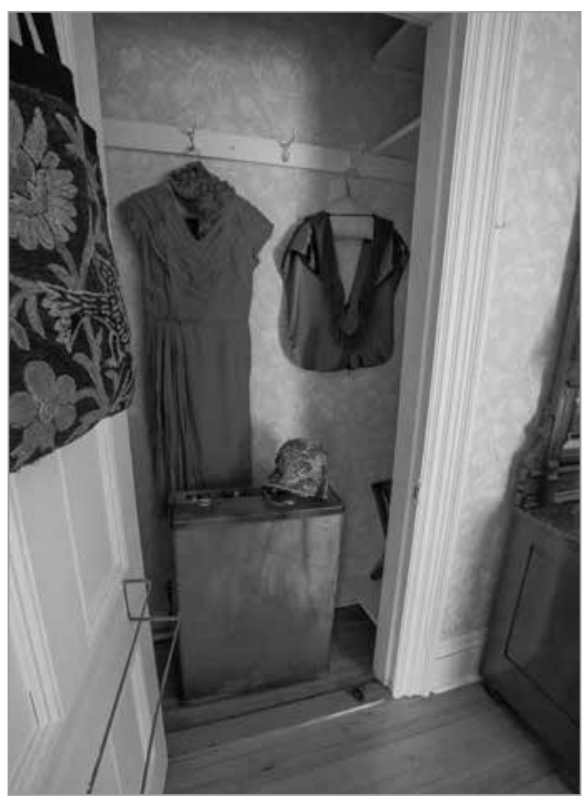

FIG. 11. THE CLOSET IN WANDA WYATT'S BEDROOM, FEATURING THE GREEN HOOD PRESENTED TO HER WHEN SHE WAS AWARDED AN HONORARY DOCTORATE FROM THE UNIVERSITY OF PRINCE EDWARD ISLAND IN 1992. | ADAM KIRKEY, 2014. $15^{\text {th }}$ of Feb. and guess it was my lucky day. The morning was fine after a heavy rain . . up at 6 a.m. quite a shock to my system I admit. Mum looked a bit dazed when I left as my departure was rather sudden in the end but I had wanted to study my singing in earnest and it was hard to do it at home. ${ }^{31}$

Her interest in music is suggested in her bedroom through the display of selected examples of her sheet music and accompanying black folio. The display of these various objects in a space that was lived in by Dorothy effectively frames the artistic personality of the eldest Wyatt daughter and inspires a dialogue about how she fit within separate sphere notions of the feminine ideal. The curation of the bedroom, supported by the in-depth interpretive tour, gives visitors an understanding of Dorothy's life as a domestically inclined yet mobile, cosmopolitan woman of Prince Edward Island's upper class.
Next to Dorothy's room was that of her younger sister, Wanda. Two years younger than Dorothy, Wanda lived a life exceptionally different from that of her older sister, and this is reflected in the curation of her bedroom (fig. 10). All members of the Wyatt family appear to have championed women's rights, and Wanda successfully participated in widening career options for Island women of the early twentieth century. The first woman from Prince Edward Island who was permitted to study in a "male" profession, Wanda was allowed to become a student of law in $1919,{ }^{32}$ following her completion of a B.A. from the Royal Victoria College, an affiliation of McGill University, in $1917 .{ }^{33}$ Wanda did not continue with her studies despite being accepted into the program, and staff at the Wyatt Heritage Properties suspect that this may have been because she felt obligated to stay home and take care of her ailing mother. Her completion of a B.A.-in many ways a unique accomplishment for the period-is referenced in the room through the display of two hardcover notebooks she used while attending the College. Wanda's tendency to travel, usually for pleasure or as a companion to her mother, is made evident through the display of travel brochures in her opened dresser drawers, and her later role in the wider community is also noted by tour guides when the green velvet hood hanging in Wanda's closet is pointed out to visitors. In recognition of her active participation in her community, particularly through her support of Island heritage and art, the University of Prince Edward Island awarded Wanda an honorary doctorate in 1992, and this hood was presented to her at the ceremony (fig. 11). ${ }^{34}$ Other examples of Wanda and Dorothy's involvement in the community are also referenced in the room. A framed certificate awarded to the Abegweit Chapter of the Imperial Order Daughters of the Empire for its efforts during World 


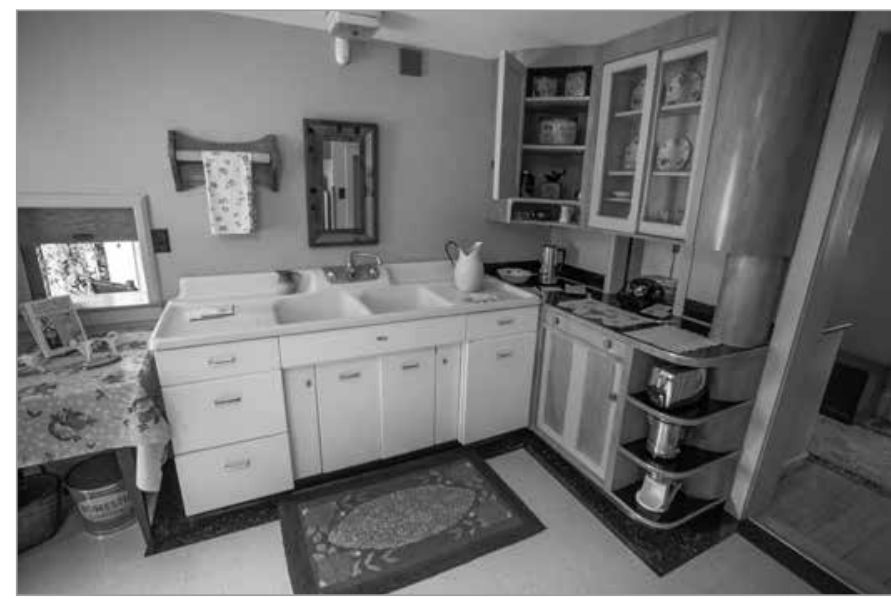

FIG. 12. A CORNER OF THE KITCHEN IN THE WYATT HISTORIC HOUSE MUSEUM, FEATURING THEIR KITCHEN QUEEN SINK. | ADAM KIRKEY, 2014.

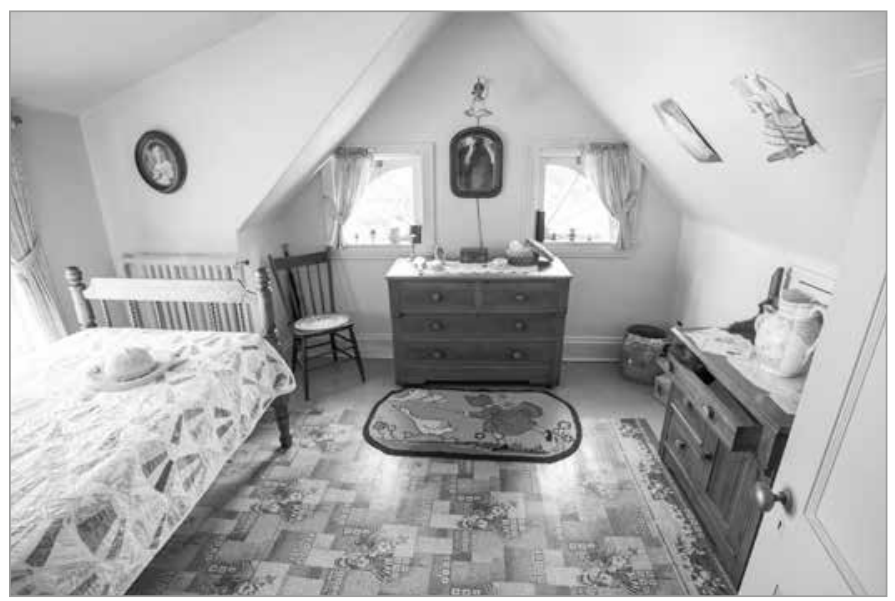

FIG. 13. THE "HIRED GIRL'S ROOM" IN THE WYATT HISTORIC HOUSE MUSEUM. | ADAM KIRKEY, 2014.
War II hangs on the wall, reminiscent of the time Wanda spent as a member of the organization. Collectively, the objects in Wanda's room provide a framing of an educated, well-travelled woman of Prince Edward Island's upper class who participated in public society by contributing to the improvement of her community. In addition to their ability to evoke narratives of their lives and interests, I maintain that Wanda and Dorothy's bedrooms comment in many ways on the women's adherence to and deviation from feminine ideals of the period. Despite Ned's prominent role in Summerside and on the Island as a whole, it is the three Wyatt women whose stories permeate the walls and contents of the home.

Other spaces in the home speak to additional women who lived and worked in the Wyatt House. Reflecting what the space would have looked like in the 1950s, the robin egg blue kitchen features the Wyatts's original kitchen queen sink, lazy Susan, and cupboards (fig. 12). ${ }^{35}$ Most of the activities that took place in that space-cleaning, cooking, ironing, washing, and polishing-would have been completed by the Wyatt family's various "hired girls" or maids. The presence of hired help provides a different kind of women's narrative to the home. The Wyatt family would typically hire one girl at a time to work for them. These girls were often of Acadian descent, a fact that could be incorporated into the interpretive tour to introduce other discussions about the history and narratives of Acadian communities and class structure in Victorian and Edwardian Prince Edward Island. Edward MacDonald explains that the Acadians, the smallest ancestral population on the Island, "came from the wrong racial stock, spoke the wrong language (French) and followed the wrong religion (Catholicism) ... from the perspective of the ruling culture."36 Consequently, the lives of many Acadian individuals were incredibly different than that of the Wyatts. The Wyatt House, even though it does cover the presence of domestic help in the home, could offer a broader historical framing of both hired help in Victorian homes and Acadian history that would serve to diversify the museum's narrative. The maid's room, located at the top of the back stairwell leading to the kitchen, is not only architecturally linked to the space most frequently occupied by the hired help, but is also painted the same robin egg blue.
These spaces, visually and architecturally connected, would serve as suitable entry points to discuss these valuable histories (fig. 13).

\section{FAMILIAL OBLIGATIONS: THE EFFECTS OF CECELIA WYATT'S HEALTH}

My darling Ned,

This is my second day out of bed after a terrible ordeal of suffering over six weeks, in fact ever since you left. It has been so hard for the dear girls up night \& day but we do hope \& pray the worst is over.

—Cecelia, Chicago 1919. ${ }^{37}$

In order to fully understand how the Wyatt family members lived in and altered the space of their home, it is essential to recognize the history of health and travel that defined Cecelia's life and how it influenced the decisions that were made by Wanda, Dorothy, and Ned. A defining element of the Wyatt family was its members' focus on Cecelia, who suffered from various gastrointestinal and bronchial health issues. Wanda and Dorothy were almost constant companions of their mother as she sought relief from her 
illnesses at sanatoria throughout North America. Cecelia's health issues are therefore key in better comprehending Wanda and Dorothy's lived experiences, as their mother's poor health affected many of the choices they made throughout their lives. Wanda's decision to not pursue a degree in law was likely because of her mother's condition. Marrying a suitable husband-an expectation placed on many women of high society-was never a reality for either Wanda or Dorothy, and this has been attributed to the fact that both girls felt an obligation to take care of their mother. ${ }^{38}$ Dorothy, in particular, spent much of her life by Cecelia's side, which appears to have limited her engagement with people her own age and the amount of time she was able to spend doing activities she enjoyed. In reviewing the Wyatt family letters and journals, I found that Cecelia commented on Dorothy's presence in many of her letters to Ned, for example: "[I] just wish Dorothy could get among some young people. She keeps close to me \& is such good company." ${ }^{39}$ Dorothy also expressed the limitations she sometimes felt in her life by writing in her diary. Passages such as "this evening Wanda \& I got raving about our ambitions \& desires for a good time. Poor Mother does not like to hear it especially as she is helpless to do anything"40 suggest how attentive Wanda and Dorothy were to their mother.

Although this narrative of health and travel is overtly recognized in other parts of the home, it is also suggested in Dorothy's bedroom, where a travelling trunk sits next to Dorothy's bed, signifying the extensive travelling Dorothy did as her mother's companion and caregiver. An ornate pair of shoes that belonged to Cecelia sits on top of the trunk, subtly alluding to the main purpose for most of Dorothy's travels. While Ned did some travelling of his own, typically for business

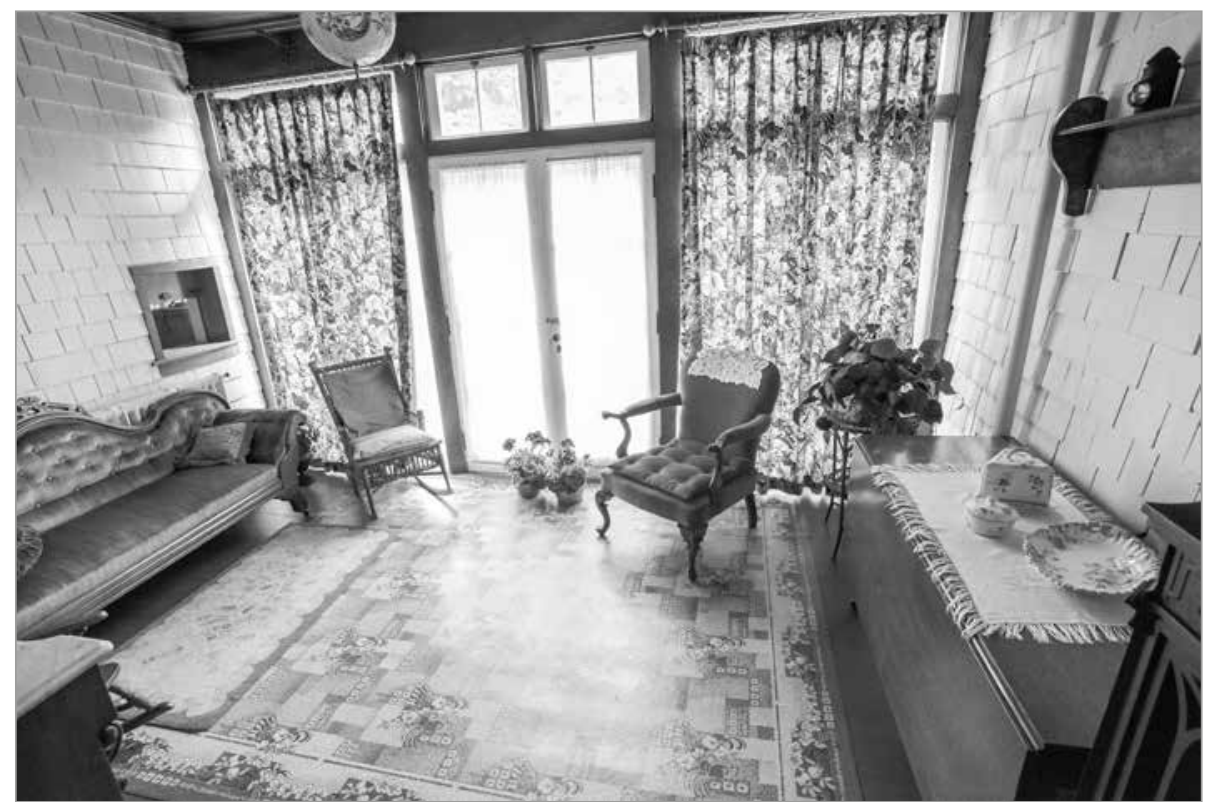

FIG. 14. THE SUN PARLOUR IN THE WYATT HISTORIC HOUSE MUSEUM. | ADAM KIRKEY, 2014.

purposes, he was often the primary resident of the Wyatt home for many months of each year. During periods when Wanda, Dorothy, and Cecelia were able to shop, attend concerts, social functions, and lectures while they were away (depending on Cecelia's condition), Ned was usually in Summerside seeing to the operations of the family home-a responsibility usually in the hands of the female-head-of-house.

\section{HEALTH AND HOME: WOMEN AS MANAGERS OF DOMESTIC INTERIORS}

Existing literature that discusses the complex relationships between women, health, and domestic spaces acknowledges the influence health concerns had in shaping the physical structure of private dwellings and the daily operations of the household in both America and Britain in the late nineteenth and early twentieth centuries. ${ }^{41}$ That period witnessed a prevalent belief that the condition of domestic interiors had a direct effect on the quality of human health, an association demonstrated by Ned's letter to Cecelia, presented at the beginning of this article. Annmarie Adams's examination of the house-body-woman relationship in late nineteenth-century Britain contextualizes this influence of medicine on architecture, and vice versa, especially in understanding women's roles during that time and the emergence of feminism. Adams explains how

\footnotetext{
the close association of houses, bodies and women around 1870 was activated through a coincidence of social factors at the time: the formulation of the germ theory, the availability of contraception, advances in women's political status and education, changing attitudes towards motherhood, the rationalization of housework, and the feminization of interior design. ${ }^{42}$
}

In such a context, women were able to exercise a certain power within domestic spaces that positioned them outside 
of their past, limited roles where reproduction and childcare were their primary responsibilities. Adams emphasizes how women were then in a position that allowed them to manage household affairs such as interior design and social events. ${ }^{43}$ As women and domestic spaces were believed to be intimately connected during that period, the additional belief that the quality or health of a home had a direct impact on the health of its inhabitants put women in the position of being the member responsible for the health of the home and, therefore, the health of the whole family. In her dissertation, Victoria Jane Solan investigates similar scenarios taking place in America. She explains how the "control of disease began in the home, and the association between health and home remained strong" in mid-nineteenthcentury America. ${ }^{44}$ Given the influence both Britain and America had on Canadian culture and society, it can be assumed that a similar system of beliefs pertaining to health, home, and gender roles also existed in Canada.

While Adams focuses on domestic architecture in British urban spaces, Solan comments on the emergence of suburban locales in America. Suburbs promised more space for the single-family home, an escape from the congested streets of cities, and a closer relationship with nature. Solan notes that the period saw an increase in the treatment of patients in "specialized building facilities such as the hospital and asylum," but it also saw the continuation of architectural construction and alteration as a means of controlling health. ${ }^{45}$ Homeowners, she explains, believed "that the design of their houses would have a significant impact on the health and character of their families, a belief which has persisted from the mid-nineteenth century to the present day." ${ }^{46}$
Cecelia Wyatt's experience with severe health issues throughout her life complicates this discussion of home, health, and women's roles as health regulators. Although she was the mother of the home, Cecelia was also the chronically ill member of the family and was therefore unable to regulate the health of the domestic spaces she and her family inhabited. Instead of hoping for relief simply through the management of their home, the Wyatts serve as an example of a family that functioned outside of the assumed lifestyles associated with the period. The exploration of this history within a house museum offers an effective revision of the domestic histories often associated with men and women from the Victorian and Edwardian eras.

\section{TRAVELLING FOR A CURE: CECELIA WYATT AND THE} NATURE CURE REGIME

The Wyatt archive holds letters, pamphlets, advertisements, and diary entries kept by the four members of the family. These documents highlight the extent of Cecelia's travelling and can be used to situate her within a broader narrative of nineteenth- and twentieth-century health treatments and practices. Even though Cecelia visited a variety of places in search of a successful cure for her chronic ailments, she most frequently stayed at Lindlahr's Sanitarium in Chicago. Established by Dr. Henry Lindlahr in 1902 , the original sanitarium located on Ashland Boulevard was complemented by a second institution in $1914 .{ }^{47}$ That second institution, Dr. Lindlahr's Health Resort, was located outside of the city in Elmhurst, Illinois. Both facilities treated their patients using "Nature Cure" or "the Cure." Based in naturopathic beliefs, the treatment emphasized the importance of vegetarianism, exercise, and exposure to air, water, and sunlight in regulating the body. A non-conventional or "deviant" medical practice, naturopathy emerged in the eighteenth and nineteenth centuries and prescribed therapies that "range[d] from diet and lifestyle advice, colonic irrigation, hydrotherapy, and electroacupuncture, to homeopathic and herbal remedies." ${ }^{48}$ While naturopathic views have continued until the present day, the popularity that these treatments gained in the early twentieth century in North America declined after 1937.49

Lindlahr's facilities offered various services for its patients in its implementation of Nature Cure. Patients, guests, and students had the opportunity to educate themselves on the treatment method through "Nature Cure literature, daily lectures and question-box talks by Dr. Lindlahr and his assistants," the idea being that after a few months the guests and patients could "return home fully equipped to be their own physicians and the health advisors of their families and their friends." The "natural remedies" practised by the Lindlahr facilities are described in their prospectus: "Curative" gymnastics, diet, hydrotherapy, osteopathy, chiropractic therapy, mud, open air and sun baths, homeopathy, herbal remedies, and diagnosis from looking at the iris of the eye..$^{50}$

The treatments issued by the sanitarium are documented in letters Cecelia sent to Ned, but also in the letters written by Wanda and Dorothy. Numerous passages from the correspondence illustrate Cecelia's adherence to Nature Cure practices and highlight the severity of her symptoms. For example, a letter from Tucson dated April 26, 1913, reads:

Have had a bronchial crisis last night. Could hardly breathe with temperature 4 degrees below normal. That does not seem good. Cannot be getting the proper kind of food 
or regular enough. When I am housed it is impossible to get food otherwise I do not feel sick. ${ }^{51}$

Keep out on the porch most of the time but I am . . . looking for better results. ${ }^{52}$

Cecelia's mentioning of the porch is significant, as is her frequent inclusion of phrases such as "I have slept out" in many of the letters she wrote to Ned while she was in Tucson. ${ }^{53}$ These inclusions indicate that Cecelia was spending lengths of time sitting and sleeping outside in the fresh air-another example of her application of Nature Cure in her daily life. A letter from Dorothy to Ned describes another occasion when Cecelia was instructed to expose her body to air and sunlight for relief: "The Doctors . . say that Mother is better but has a lot to get rid of yet. She still has the cough and has not much strength. We have been going up to the roof nearly every day and the sun has brought a rash out on her chest and back and the Doctors are delighted." 54 Later documents, such as a 1918 dairy entry written by Dorothy that states "Mother a little better. We got her fixed up in the sun parlour," 55 show how the use of such spaces remained a constant practice in Cecelia's life. In addition to the information they provide about the naturopathic ideology Cecelia was applying to her daily routine, passages such as these can be used to illuminate the physical structure of the Wyatt House.

\section{THE FEMINIZATION OF SPACE: CECELIA AND THE SUN PARLOUR}

The many references to Cecelia spending time under the sun or in sun parlours as a means of treatment are also reflected in the Wyatt home in Prince Edward Island. After moving into the home in the 1890s, the Wyatts subsequently began making alterations to its exterior and interior as a reflection of their own personal tastes and desires. Examples of structural changes that were made to the house include the pushing back of the front entranceway hall staircase and the creation of a new attic entrance. Although the exact date for that renovation is undetermined, a second phase of renovations was carried out in 1928 under the direction of architect James Edward Harris, a nephew of esteemed Island architect William Critchlow Harris. ${ }^{56}$ The changes to the house included an improvement to the attic with the installation of Palladian windows and built-in storage spaces under the eaves, the construction of a vestibule with Doric columns, ${ }^{57}$ the embellishment of the living room's focal fireplace flanked by white bookcases, and the enclosure of the former open porch for the purpose of creating the Wyatts's sun parlour. ${ }^{58}$ Located off the dining room, the sun parlour features a space for seating and a decorative sideboard that holds some of the Wyatts's cherished dishware (fig. 14). The sun parlour is made up of three pale yellow shingled interior walls and one exterior wall, which is composed almost entirely of French doors and two large windows. Providing a pleasing view of the Wyatts's back lawn, the doors lead to a small outdoor porch ideal for sitting in the fresh air.

I argue that taken collectively, many of the structural renovations made to the home can be understood in the context of the feminization of space. This "feminization" of an interior is conceptualized in the same way that the term is used by Adams and Spampinato, expressing the "social/ cultural process that extends beyond the mere act of shaping space toward an individual's own need" and to create a space that is reflective of the "family's cultural landscape." 59 Specifically, the sun parlour as an architectural alteration also functions as an example of managing a domestic space for the purpose of healthcare. The repetitive references in the family letters and documentation of Cecelia spending time in bright, windowfilled sun parlours or airy porches while travelling supports the interpretation that the Wyatts's sun parlour was created so that Cecelia could continue to do this from her home. Many of the archival documents that include phrases about this simple method of treatment date from the 1910s and 1920s-before the construction of the Wyatts's sun parlour. After having the ability to spend time in such readily available rooms while she was travelling, it is likely that Cecelia wanted access to similarly designed spaces in the comfort of her own home. In comparison to the home's living room-a public space designed to receive and entertain guests while demonstrating the family's wealth and social standing through its display of fine furnishings and possessions ${ }^{60}$ - the sun parlour functioned as both a public and a private space where Cecelia could enjoy a quiet, sunny morning in solitude or in the company of close acquaintances. The sun parlour's easy access to the outdoor lawn would have allowed her to quickly leave the house to walk outside in the fresh air or sit inside with a door ajar-enabling her to follow Dr. Lindlahr's prescribed daily air baths.

The inclusion of this room on the tour of the Wyatt House brings the history of Cecelia's travelling outside of the home for health treatments into the domestic space and exemplifies how architectural elements of a home can narrate a history that happened outside of its walls. Although the sun parlour is seemingly less exotic than the living room, with its elaborate furnishings and other objects of curiosity, it nonetheless carries subtle traces of travel through its architecture. As a physical alteration made to the home while the Wyatts lived there, the 
sun parlour is evidence of a conscious decision that was made by the family and it provides valuable information about their personal tastes. While she did not manage her house for the purpose of regulating the health of her family in the traditional sense, as discussed by Adams and Solan, Cecelia applied the treatment she received in the various sanatoria she visited to the architecture of her own home.

\section{CONCLUSION}

This article has championed the examination of historic house museums as valuable objects that reveal details about a home's past female inhabitants. By using material culture methodology, it becomes clear that the architecture and interior spaces of a home can be read as artifacts, signifying that house museums can take on added meaning as sites of historic exploration and understanding. Although interiors are spaces difficult to study because of their mutability over time, historic house museums offer particularly fertile spaces for inquiry because of the documents and collections associated with them.

As previously lived-in, private dwellings, house museums and their accompanying collections can be mined for physical evidence of how their domestic spaces were created, altered, and used by earlier occupants. As present-day public spaces, house museums can then be used to frame unconventional or neglected histories based on their materiality, serving as alternative spaces to explore more challenging and diverse narratives about our past.

Because of the associations that existed between domestic interiors and women of the nineteenth and twentieth centuries, I argue that historic house museums can be used to draw specific attention to women's histories and the critical roles they played in shaping the physicality of their own homes. Like Carrollcroft House, examined by Adams and Spampinato, the architecture of the Wyatt Historic House Museum provides contextualization of women's lived experiences and the agency women often held in determining the design and use of their homes. Although the Wyatt House serves as an exemplary house museum model because of its rich archive and original collection of objects, other historic homes in Canada could also reveal more intimate and diverse histories about public and private lives. In addition to the value placed on historic house museums via more conventional architectural histories, these spaces should also be acknowledged as historic objects with the ability to complicate our understanding of interiors, women, and domestic spaces.

\section{NOTES}

1. Ned Wyatt to Cecelia Wyatt, June 23, 1913, MacNaught History Centre and Archives, Summerside, PE, box "Correspondence Ned/ Cel/Dorothy," folder "To Cecelia from Ned June-Dec. 1913, Chicago, III."

2. See for example: Meethan, Kevin, 2001, Tourism in Global Society: Place, Culture, Consumption, New York, Palgrave; Terry, Andrea, 2013, "Gender, Canadian Nationhood and 'Keeping House': The Cultural Bureaucratisation of Dundurn Castle in Hamilton, Ontario, 1900-1960s," Gender \& History, vol. 25, no. 1, p. 47-64; Bos, Brittney Anne, 2011, "Historical Memory and the Representation of History: Forging Connections Between National Historic Sites and Gender History," Conserveries mémorielles, no. 9, [http:// cm.revues.org/836], accessed April 12, 2019; McKenna, Katherine M.J., 2005, “Women's History, Gender Politics and the Interpretation of Canadian Historic Sites: Some Examples from Ontario," Atlantis: A Women's Studies Journal, vol. 30, no. 1, p. 21-30; Radu, Stephanie Karen, 2014, "Representation, Preservation \& Interpretation at Canada's
House Museums," Ph.D. dissertation, Western University, London, ON.

3. West, Patricia, 1999, Domesticating History: The Political Origins of America's House Museums, Washington and London, Smithsonian Press, p. 40-41.

4. Ibid.

5. Quinn, Laura L., 2001, The Telling is Slant: Historic House Museums and the Re-creation of the Past, Ph.D. dissertation, University of Rochester, Rochester, NY, p. 2; Gordon, Alan, 2016, Time Travel: Tourism and the Rise of the Living History Museum in Mid-twentiethcentury Canada, Vancouver, University of British Columbia Press.

6. The examination of the politics inherent in Canadian historic house museums has most recently been provided by art historian Andrea Terry in her 2015 publication Family Ties: Living History in Canadian House Museum, Kingston and Montreal, McGillQueen's University Press.

7. Smith, Charlotte, 2002, "Civic Consciousness and House Museums: The Instructional Role of Interpretive Narratives," Australasian Journal of American Studies, vol. 21, no. 1, p. 74-88.

8. An example of a house museum that has successfully included alternative histories in its curation and interpretation is the Lower East Side Tenement Museum in Manhattan. This tenement, comprised of twenty apartments, narrates the history of working class immigrants. The site offers a selection of tours that reflect the experiences of Irish, ItalianCatholic, and German-Jewish families that lived in the tenement between the 1860s and 1930s. This museum is explored in Christensen, Kim, 2011, "Ideas Versus Things: The Balancing Act of Interpreting Historic House Museums," International Journal of Heritage Studies, vol. 17 , no. 2 , p. 153-168, at p. 161-163.

9. Young, Linda, 2002, “A Woman's Place Is in the House... Museum: Interpreting Women's Histories in House Museums," Open Museum Journal: Interpreting Historic House Museums, vol. 5, p. 1-24.

10. McTavish, Lianne, 2008, "Strategic Donations: Women and Museums in New Brunswick, 1862-1930," Journal of Canadian Studies, vol. 42, no. 2, p. 93-116; West, Patricia, 2003, "Uncovering and Interpreting Women's History at Historic House Museums," in Gail Lee Dubrow and Jennifer B. Goodman (eds.), Restoring Women's History Through Historic Preservation, Baltimore and London, John Hopkins University Press, p. 83-95; Howe, 
Barbara J., 2003, "Women in the Nineteenthcentury Preservation Movement," in Dubrow and Goodman (ed.), id., p. 736.

11. Duncan, Carol, 1991, "Art Museums and the Ritual of Citizenship," in Ivan Karp and Steven D. Lavine (eds.), Exhibiting Cultures, Washington and London, Smithsonian Institution Press, p. 88-103.

12. Numerous academics have complicated the traditionally defined roles of the "domestic sphere" and the "public sphere," illustrating how men and women both had influence and agency in each "separate" sphere. For example, while women did spend more time in their domestic interiors than men, women, as Adams explains, played a role in the "public" sphere of home economics by often taking charge of hiring domestic help, organizing social events, and purchasing many of the items used by members of the family, such as food and clothing. As well, separate sphere ideologies were often applied to a specific experience, namely that of middleand upper-class Caucasian women. While it is beyond the scope of this article to review these criticisms in detail, some examples of the revisions include: Adams, Annmarie, 2006, "Female Regulation of the Healthy Home," in James Opp and John C. Walsh (eds.), Home, Work, and Play: Situating Canadian Social History, 1840-1980, Toronto, Oxford University Press, p. 117; Ferry, Emma, 2003, "'Decorators May be Compared to Doctors': An Analysis of Rhoda and Agnes Garrett's "Suggestions for House Decoration in Painting, Woodwork and Furniture (1876)," Journal of Design History, vol. 16, no. 1, p. 15-23; and for a specific examination of Prince Edward Island women, McDonald-Rissanen, Mary, 2015, In the Interval of the Wave: Prince Edward Island Women's Nineteenth- and Early Twentiethcentury Life Writing, Montreal and Kingston, McGill-Queens University Press, p. 27-57.

13. Kolk, Heidi Aronson, 2013, "The Manylayered Lives of Things: Experiments in Multidisciplinary Object Study at a Local House Museum in St. Louis," Winterthur Portfolio, vol. 47, no. 23, p. 161-196; Hoskins, Janet, 2008, Biographical Objects: How Things Tell the Stories of People's Lives, New York and London, Routledge; Bal, Mieke, 2004, "Telling Objects: A Narrative Perspective on Collecting," in Donald Preziosi and Claire Farago (eds.), Grasping the World: The Idea of the Museums, Burlington, Ashgate, p. 84-102.
14. Prown, Jules David, 1982, "Mind in Matter: An Introduction to Material Culture Theory and Method," Winterthur Portfolio, vol. 17, no. 1, p. 2.

15. Baudrillard, Jean, 2013, "Structures of Interior Design," in Graeme Brooker and Sally Stone (eds.), From Organization to Decoration: An Interiors Reader, London, Routledge, p. 125-129.

16. Adams, Annmarie and Silvia Spampinato, 2010, "Carrollcroft as Women's Space: An Architectural History," Journal of Eastern Townships Studies, vol. 35, p. 21-48, at p. 22. Carrollcroft remained the home of the Colby family for several generations starting in 1859.

17. Id., p. 22.

18. Id., p. 31.

19. Agnew, Jean-Christophe, 2012, "A House of Fiction: Domestic Interiors and the Commodity Aesthetic," in Chiara Briganti and Kathy Mezel (eds.), The Domestic Reader, Toronto, University of Toronto Press, p. 133-135; Kingwell, Mark, 2004, "Tables, Chairs, and Other Machines for Thinking," in Practical Judgments: Essays in Culture, Politics, and Interpretation, Toronto, University of Toronto Press, p. 229-247, at p. 241.

20. MacDonald, Edward, 2000, If You're Stronghearted: Prince Edward Island in the Twentieth Century, Charlottetown, Prince Edward Island Museum and Heritage Foundation, p. 7.

21. Mary McDonald-Rissanen's 2015 publication, In the Interval of the Wave (op. cit.), is an exception. Here, the author contextualizes both urban and rural Island culture and society during the mid-nineteenth and early twentieth centuries by examining women's life writings, namely in the form of journals.

22. Cecelia was the daughter of the Honourable John Lefurgey, a prominent local shipbuilder and merchant from Summerside. In 1870, Lefurgey was elected to the Prince Edward Island Legislature. He remained a member of the Executive Council for twenty years and was an "ardent advocate" of Confederation, as noted in Kessler, Deirdre, 1999, A Century on Spring Street: Wanda Lefurgey Wyatt of Summerside, Prince Edward Island, 18951998, Charlottetown, Indigo Press, p. 6. Additionally, shipbuilding provided the backbone of Summerside's economy during the last quarter of the nineteenth century. As Horne notes, "due to the impact of shipbuilding, by the 1880 s Summerside was the commercial capital of Prince County and the western half of Prince Edward Island." Horne, Fred, 2002 Images of our Past: Historic Summerside, 1900 1970, Halifax, Nimbus Publishing Limited, p. xiv.

23. McDonald-Rissanen, In the Interval of the Wave, p. 45.

24. Experience Summerside. Arts, Heritage and Culture, Wyatt House History, last modified 2013, [http://culturesummerside.com], accessed October 29, 2013.

25. Kessler, A Century on Spring Street, op. cit. Ned was also the Speaker of the House from 1912 to 1916.

26. Experience Summerside. Arts, Heritage and Culture, n.d., History: Culture Summerside, [http://culturesummerside.com/about-us/ history/], accessed March 9, 2019.

27. Local newspapers such as The Journal would often reference parties and social gatherings that would take place at the Wyatt residence. An excerpt from the February 8, 1905, Journal, for instance, reads that "Mr. and Mrs. J.E. Wyatt gave a very enjoyable party at their home on Friday evening last, when they entertained a number of their friends to whist and dancing."

28. Situated on an angle facing Ned's desk, the rocking chair and sewing table were placed in the study based on excerpts from Wanda's diaries. Phrases such as " $D$ [orothy] is practicing and $M$ [other] is doing some fancy work in the library" (Wanda Wyatt in her diary, October 28, 1927) indicate that Cecelia spent time in that space as she worked on what were likely embroidery and other sewing projects.

29. It should be noted that both the bed skirt and the vanity covering are reproductions made by the original curators of the house to replace the aging ones that were found on the furniture after the city received the home. Susan Rodgers (original curator of the Wyatt Historic House Museum), in a discussion with the author, April 2015.

30. Dorothy Wyatt to Wanda Wyatt, n.d., box "Correspondence Dorothy," folder "1929 to Family from Dorothy," MacNaught History Centre and Archives, Summerside, PE.

31. Dorothy Wyatt, March 1, 1925, box "Dorothy," folder "Dorothy Randal Wyatt 1916-1918, vol. I, 1918-1920, vol. II (in exhibit)," MacNaught History Centre and Archives, Summerside, PE.

32. "Miss Wyatt to Study Law," The Guardian Newspaper, Charlottetown, PE, December 1, 1919, p. 5. 
33. Kessler, A Century on Spring Street, p. 127.

34. Id., p. 442.

35. The kitchen queen sink was bought and installed in 1958 by Wanda, as detailed in her 1928 diary. Appliances such as the fridge and stove are two examples of objects that were brought in during the curation of the home to reflect the models the Wyatts had at the time.

36. MacDonald, If You're Stronghearted, p. 15.

37. Cecelia Wyatt to Ned Wyatt, April 3, 1919, box "Correspondence Ned," folder "To Ned from Family in Chicago 1919," MacNaught History Centre and Archive, Summerside, PE.

38. An interview between Mary O'Brien of the University of Prince Edward Island and Wanda Wyatt in 1984 reveals the obligation she felt. In discussing her hopes for her future as a young girl, Wanda stated: "The fact that my mother wasn't well, I felt my responsibility to the family. And my getting out on my own would be a very selfish thing to do, under the circumstances. And that's the way it proved, you see. I could have gone out, and forsaken the family, gone out on my own, but I didn't." She later explained that if her mother had been well, it "would have been an entirely different story altogether. If you didn't have that feeling that somebody must be there to look after her, it would have been different. You would have had a feeling of freedom, and of going out on your own and testing yourself, your own wings." Wanda Wyatt, interview by Mary O'Brien. December 4, 1984, University of Prince Edward Island, interview transcript available in Wyatt fonds "Personal Papers," MacNaught History Centre and Archives, Summerside, PE, p. 12.

39. Cecelia Wyatt to Ned Wyatt, April 6, 1913, box "Correspondence Ned/Cel/Dorothy," folder "To Ned from Cecelia \& Dorothy in U.S. Apr.-May 1913," MacNaught History Centre and Archives, Summerside, PE.

40. Dorothy Wyatt in her diary, May 24, 1918, box "Dorothy," folder "Dorothy Randal Wyatt 1916-1918, vol. I, 1918-1920, vol. II (in exhibit)," MacNaught History Centre and Archives, Summerside, PE.

41. Solan, Victoria Jane, 2004, "'Built for Health': American Architecture and the Healthy House, 1850-1930," Ph.D. dissertation, Yale University, New Haven, CT; Adams, Annmarie, 1996, Architecture in the Family Way, Doctors, Houses and Women 1870-1900, Montreal and Kingston, McGill-Queen's University Press.
42. Adams, id., p. 4.

43. Id., p. 6.

44. Solan, "'Built for Health': American Architecture," p 8.

45. Id., p. 14.

46. Id., p. 15.

47. Wilson, Nancy, n.d., "The Lindlahr Sanitarium," The City of Elmhurst, [https://www.elmhurst. org/DocumentCenter/Home]; pdf available at [https://www.elmhurst.org/DocumentCenter/ View/261], accessed October 20, 2013.

48. Gort, Elaine H. and David Coburn, 1988, "Naturopathy in Canada: Changing Relationships to Medicine, Chiropractic and the State," Social, Science \& Medicine, vol. 26, no. 10, p. $1061-1072$, at p. 1061.

49. Id., p. 1063.

50. "Prospectus of the Lindlahr Nature Cure Institutes inc.," c. 1914, Chicago, IL, box "Cecelia," folder "Prospectus - Lindlahr Nature Cure," MacNaught History Centre and Archives, Summerside, PE.

51. Phrases such as this, as well as entries in Wanda's and Dorothy's diaries, indicate that Cecelia was not staying at the actual sanitarium in Tucson but was instead residing in an apartment nearby. This was typical of the family for most places that they travelled and planned to stay for some time. Another example of the Wyatt family living in an apartment rather than a sanitarium Cecelia was visiting for treatment is detailed in Dorothy's diary from 1918-1920. On December 3, 1918, Dorothy mentions how she, Wanda, and Cecelia "found a new flat" in Chicago and her entry on December 13 describes their new space: "our livingroom faces South with a sun parlour. Then the bedroom is east (not much of an outlook but better than the other. Mother does not like the bed much to sleep in though it and the rest of the set are lovely. The dining room is very pretty too they have a very nice walnut set \& the kitchen is a dream, it is fun to work in it." Dorothy's description of the space speaks to her interest in interior design and is indicative of the relationship between women and their domestic interiors.

52. Cecelia Wyatt to Ned Wyatt, April 26, 1913 , box "Correspondence Ned," folder "To Ned from Cecelia \& Dorothy in U.S. Apr.-May 1913," MacNaught History Centre and Archives, Summerside, PE.

53. Ibid.
54. Dorothy Wyatt to Ned Wyatt, March 30, 1913, box "Correspondence Ned/Cel/Dorothy," folder "To Ned from Cecelia in Chicago 1913," MacNaught History Centre and Archives.

55. Dorothy Wyatt in her diary, May 23, 1918, box "Dorothy," folder "Dorothy Randal Wyatt 1916-1918, vol. I, 1918-1920, vol. II (in exhibit)," MacNaught History Centre and Archives, Summerside, PE.

56. There are various references to meeting with "Mr. Harris" in Wanda's diary from 1928.

57. Canada's Historic Places, Wyatt Historic House, 2014, [http://www.historicplaces.ca/ en/rep-reg/place-lieu.aspx?id=2612], accessed March 28, 2014.

58. Historic Places: Prince Edward Island, n.d., Wyatt Historic House, [http://www.gov.pe.ca/ hpo/app.php?nav =details $\& p=6234]$, accessed March 9, 2019. Wanda's journal entries from 1928 also document the various meetings the family had with Harris and the ongoing discussions about the sun porch.

59. Adams and Spampinato, "Carrollcroft as Women's Space," p. 23.

60. Ward, Peter, 1999, A History of Domestic Space: Privacy and the Canadian Home, Vancouver, University of British Columbia Press, p. 62. 